New Jersey History 124:1

\title{
"A More Accurate and Extensive Education than is Customary": Educational Opportunities for Women in Early-Nineteenth-Century New Jersey
}

\author{
Lucia McMahon ${ }^{1}$
}

\begin{abstract}
This article examines the variety of educational opportunities available to New Jersey women in the first half of the nineteenth century. While largely ignored in the national historiography on women's education, numerous groundbreaking schools for women were established throughout New Jersey in the early nineteenth century. The Newark Academy offered instruction to women since the late eighteenth century; its successor, the Newark Institute for Young Ladies, referred to its curriculum as "collegiate" decades before women were admitted to colleges. In the 1830s, the Bloomfield Female Seminary maintained a reputation for scholarly excellence; throughout the 1840s, the Mount Holly Female Seminary offered a course of study for women seeking to become teachers. By the $1840 \mathrm{~s}$, schools could be found in various cities and towns, including Bloomfield, Bordentown, Burlington, Freehold, Lawrenceville, Newark, New Brunswick, Rahway, and Raritan. The New Jersey schools examined in this essay shed light on both local and national practices of women's education. As women's access to education expanded, so did debates about the appropriate uses of education. While many men supported women's education, women understood that they could be subject to criticism from those who feared the consequences of their intellectual pursuits. Analysis of the forms, purposes, and uses of women's education, as evident in these New Jersey case studies, illustrates both the opportunities and challenges that teachers, students, and supporters faced as they sought to expand women's institutional access to education.
\end{abstract}

On July 21, 1826, Reverend Henry Powers of Trinity Church delivered an address on "Female Education" at a ceremony commemorating the first anniversary of the Newark Institute for Young Ladies. As Powers proudly noted, the faculty at this school "have entered upon a bold experiment: it is the Reformation of Female Education." In an effort "to awaken the public mind to its importance and practicability," Powers published his lengthy address ("by request," as he noted), along with a catalogue detailing the school's course of study, a list of the 125 pupils attending the institute, and extracts from the "Report of the Examining Committee." As these documents reveal, the Newark Institute offered an extensive curriculum, including courses in grammar, arithmetic, elocution, geography, natural philosophy, chemistry, botany, mineralogy, and geology. The study of Latin, Greek, French, or Spanish languages was also available to those students pursuing the "second course" of study. At the end of the school year, students took part in public ceremonies, where they were examined in various subjects, and "honours were distributed to the distinguished of those young ladies." The students passed their examinations with flying colors, and according to the Examining Committee, these young women would be "accomplished, respected, and useful in any sphere of life." The

\footnotetext{
${ }^{1}$ Lucia McMahon is an assistant professor of history at William Paterson University. She is completing a manuscript on women, education and sociability in early national America.
}

[Copyright by author(s)]

(c) \$ Except where otherwise noted, this work is licensed under http://creativecommons.org/licenses/by-nc-nd/3.0/ 
Newark Institute for Young Ladies, they confidently asserted, was "becoming equal in character with any other in the United States."

The serious attention that the teachers, trustees, and pupils of the Newark Institute for Young Ladies accorded to women's education was indicative of larger trends that emerged during the early national period. In the decades following the American Revolution, an enlightened faith in the transformative powers of education swept the nation, as political thinkers stressed the need for a well-educated citizenry. Women as well as men benefited from this increased attention to education, as educators increasingly emphasized "the high importance of female education.," Educators established scores of schools for young women throughout the nation, providing mostly white, middle- and upper-class women with unprecedented educational opportunities. ${ }^{4}$ The most well-known and well-studied of these institutions include the Young Ladies' Academy of Philadelphia; Sarah Pierce's academy in Litchfield, Connecticut; Emma Willard's Troy Female Seminary; Catherine Beecher's school in Hartford, Connecticut; and Mount Holyoke in South Hadley, Massachusetts, founded by Mary Lyon. ${ }^{5}$

\footnotetext{
${ }^{2}$ Rev. Henry P. Powers, An Address, Delivered in Trinity Church, Newark, N.J. on the Anniversary of the Newark Institute for Young Ladies, July 21, 1826 (Newark: Printed by M. Lyon and Co., 1826), 3-22. Powers's support of female education is briefly mentioned in Frank J. Urquhart, A History of the City of Newark, New Jersey, Embracing Practically Two and a Half Centuries (New York: Lewis Historical Publishing Co., 1913), 977.

${ }^{3}$ Quotation is from article entitled "Education," which included a reprint of a broadside advertisement for the Newark Female Academy, in The Port-Folio (Philadelphia), April 17, 1802, 116. For general overviews of educational improvements and the "diffusion of knowledge" in the early republic, see Richard Brown, Knowledge is Power: The Diffusion of Information in Early America, 1700-1865 (New York: Oxford University Press, 1989); Lawrence A. Cremin, American Education: The National Experience, 1783-1876 (New York: Harper \& Row, 1980); William J. Gilmore, Reading Becomes a Necessity of Life: Material and Cultural Life in Rural New England, 1780-1835 (Knoxville: University of Tennessee Press, 1989); J. M. Opal, "Exciting Emulation: Academies and the Transformation of the Rural North, 1780s-1820s," Journal of American History 91, no. 2 (2004): 445-470; and idem, Beyond the Farm: National Ambitions in Rural New England (Philadelphia: University of Pennsylvania Press, 2008); and James D. Watkinson, "Useful Knowledge? Concepts, Values, and Access in American Education, 1776-1840," History of Education Quarterly 30, no. 3 (1990): 351-70.

${ }^{4}$ A note about my use of terms to describe my historical subjects: throughout this essay, I refer to the students who attended female academies, seminaries, and institutes as "women" or "young women." The most common nineteenth-century terms used to describe these students were "females" or "young ladies;" they were almost never referred to as "girls" in any of the primary sources I have examined. When discussing the aims of their schools, educators explicitly made reference to "women's education" or "female education," or "the education of women," rather than the "education of girls." Here, I also follow the lead of Mary Kelley, a leading scholar of women's education in the early American republic. See Mary Kelley, Learning to Stand and Speak: Women, Education and Public Life in America's Republic (Chapel Hill: University of North Carolina Press, 2006). Although some schools admitted girls as young as 9 or 10, the majority of students were 13-18 years of age or older. This was especially true of "seminaries" and "institutes," schools that increasingly sought to provide the equivalent of college curriculum to their students. By the 1830s and 1840s, many seminaries began to set minimum age requirements of at least 15 or 16 years old. This is roughly equivalent to the age of most men attending college at this time, which Colin Burke estimates at 15-20 years old. See Colin Burke, American Collegiate Populations: A Test of the Traditional View (New York: New York University Press, 1982).

${ }^{5}$ The historiography of women's education in the United States has grown over the past decades. One of the first works to study female academies and recognize their historical significance was Lynne Templeton Brickley, "Sarah Pierce's Litchfield Female Academy, 1792-1833,” Ed.D. Diss., Harvard University, 1985.
} 
While largely ignored in the national historiography on women's education, New Jersey also boasted innovative schools for young women. ${ }^{6}$ The Newark Academy had offered instruction to women since the late eighteenth century, and operated as a co-educational institution for part of its history. Its successor, the Newark Institute for Young Ladies, referred to its curriculum as "collegiate" decades before women were admitted to colleges. In the early nineteenth century, several gentlemen affiliated with Queen's College (later Rutgers University) established a Female Academy in New Brunswick. In the 1830s, the Bloomfield Female Seminary maintained a reputation for scholarly excellence; throughout the 1840s, the Mount Holly Female Seminary offered a specific course of study for women seeking to become teachers. As my research indicates, numerous groundbreaking schools for women were established throughout New Jersey in the first half of the nineteenth century. By the 1840s, well-respected schools could be found in various cities and towns, including Bloomfield, Bordentown, Burlington, Freehold, Lawrenceville, Newark, New Brunswick, Rahway, and Raritan.

Moving chronologically through the first half of the nineteenth century, this essay will explore the variety of educational opportunities available to young women in New Jersey. While drawing attention to New Jersey women's education, this essay also seeks to connect local history to a national narrative. The records of lesser-known New Jersey institutions can shed valuable light on local histories, while also serving to re-map the larger educational world of women in nineteenth-century America. A focus on New Jersey's educational history demonstrates that the significant gains in women's education that occurred during the nineteenth century were not limited to New England or New York, the areas most covered in the historiography. New Jersey educators established

For a summary of recent research findings on the establishment of female academies and the students who attended them, see Nancy Beadie and Kim Tolley, eds., Chartered Schools: Two Hundred Years of Independent Academies in the United States, 1727-1925 (New York: RoutledgeFalmer: 2002); and the essays collected for a symposium on "Reappraisals of the Academy Movement," History of Education Quarterly 41, no. 2 (2001): 216-270. For recent studies of antebellum women's educational experiences, see Kelley, Learning to Stand and Speak; and idem, “'The Need of Their Genius': Women's Reading and Writing Practices in Early America," along with several essays responding to Kelley's book collected for a symposium entitled, "Women and Civil Society," Journal of the Early Republic 28, no. 1 (2008): 1-82; and Margaret Nash, Women's Education in the United States 1780-1840 (New York: Palgrave Macmillan, 2005).

${ }^{6}$ There has been very little scholarly attention paid to New Jersey women's educational experiences. For a brief discussion of New Jersey women's education, see Carmela Ascolese Karnoutsos, New Jersey Women: A History of Their Status, Roles, and Images (Trenton: New Jersey Historical Commission, 1997), $26-31$. The first classic, comprehensive study on American women's education, published in 1929 by Thomas Woody, focused on well known academies, including the Young Ladies' Academy of Philadelphia, Emma Willard's Female Seminary at Troy, the Litchfield Academy founded by Sarah Pierce, and Catherine Beecher's Hartford Academy. While Woody uncovered evidence of numerous schools, many of his examples are drawn from New England, and there is almost no mention of New Jersey in his lengthy study. See Thomas Woody, A History of Women's Education in the United States (1929; reprint, New York: Octagon Books, 1980). This trend has continued even in the recent historiography. A recent, comprehensive study of women's educational history from 1780-1840 lists only four New Jersey schools for women in its appendix; one of these, the Rutgers Female Institute, was actually located in New York. The three New Jersey schools mentioned are: The Newark Institute for Young Ladies; Spring-Villa Female Seminary, and St. Mary's Hall. See Nash, Women's Education in the United States, Appendix, 119. 
numerous schools for women; wrote essays about the importance of women's education; and publicly celebrated women's intellectual achievements.

While framing the history of New Jersey schools within both a local and national narrative, this essay also examines larger issues about the forms, purposes, and uses of women's education. The subject of women's education remained in the public eye throughout the nineteenth century. Nearly all female academies and seminaries held some sort of "public" examination or commencement ceremonies, during which teachers or trustees tested the students' progress in several subjects. Accounts of these ceremonies were published in various newspapers and periodicals, along with numerous other pamphlets, essays, and catalogues about women's education. These activities and publications firmly placed female students and the subject of women's education within a larger "public sphere" of civic society. ${ }^{7}$ Educated women were active participants - as well as the objects of scrutiny and debate -- in the public and print spheres of antebellum America.

Frequent publications about the practices, ideals, and consequences of women's education revealed concerns and preoccupations about proper gender roles and prescribed "spheres" for men and women. ${ }^{8}$ Throughout the first half of the nineteenth century, women's institutional access to education was marked by two related, but competing, characteristics. On one hand, women enjoyed unprecedented access to a variety of schools - progress that clearly paved the way for women's entrance into colleges and other institutions of higher education (including law and medical schools). ${ }^{9}$ On the other

\footnotetext{
${ }^{7}$ For an overview of how public and civic culture operated in the early national period, see Kelley, Learning to Stand and Speak; and David Waldstreicher, In the Midst of Perpetual Fetes: The Making of American Nationalism (Chapel Hill: University of North Carolina Press, 1997). For further exploration of the connections between women's education and civil society on a national level, see Lucia McMahon, "“Of the Utmost Importance to Our Country': Women, Education, and Society, 1780-1820," Journal of the Early Republic (forthcoming).

${ }^{8}$ For overviews of "separate spheres" ideology and its effects on nineteenth-century women's lives, see Linda Kerber, "Separate Spheres, Female Worlds, Woman's Place: The Rhetoric of Women's History," Journal of American History 75 (1988): 9-39; and Linda Kerber et al., "Forum: Beyond Roles, Beyond Spheres: Thinking About Gender in the Early Republic," William and Mary Quarterly 46 (1989): 565-81. It should be noted that separate spheres ideology did not necessarily represent the lived experiences of women, but rather was primarily prescriptive and didactic in nature. For works that specifically challenge the separate spheres framework by suggesting the presence of fluid interactions between men and women, see Karen Hansen, A Very Social Time: Crafting Community in Antebellum New England (Berkeley: University of California Press, 1994); Catherine Kelly, In the New England Fashion: Reshaping Women's Lives in the Nineteenth Century (Ithaca: Cornell University Press, 1999); Charlene M. Boyer Lewis, Ladies and Gentlemen on Display: Planter Society at the Virginia Springs, 1790-1860 (Charlottesville: University Press of Virginia, 2001); and Laura McCall and Donald Yacovone, eds., A Shared Experience: Women, Men and the History of Gender (New York: New York University Press, 1998).

${ }^{9}$ For women's access to college in the nineteenth century, see Roger L. Geiger, ed., The American College in the Nineteenth Century (Nashville: Vanderbilt University Press, 2000), especially 169-195; Helen Lefkowitz Horowitz, Alma Mater: Design and Experience in the Women's Colleges from Their NineteenthCentury Beginnings to the 1930s (New York: Knopf, 1984); Barbara Miller Solomon, In the Company of Educated Women: A History of Women and Higher Education in America (New Haven: Yale University Press, 1985); and Linda Eisenmann, "Reconsidering a Classic: Assessing the History of Women's Higher Education a Dozen Years After Barbara Solomon," Harvard Educational Review 67, no. 4 (1997): 689717. Eisenmann's essay underscored the need for an educational history of women that extended beyond a
} 
hand, as women's access to education expanded, so did debates about what roles educated women should play in society. While many men supported women's education, women understood that they could be subject to criticism and derision from those who feared the consequences of their intellectual pursuits. Critics argued that "the mental faculties of females are not equal to those of the male sex," while proponents of women's education countered that with "equal advantages, the intellectual attainments of women may equal those of men." Yet educators also assured the public that women had no desire to "travel out of their native sphere," thus garnering support for their institutions, even as they reinforced prescriptive ideas about women's proper roles in society. As new female academies and seminaries were established, numerous publications reminded the public both of the impressive intellectual achievements of educated women, and of the idea that women should never use education to pursue "masculine attainments." 10 These competing discourses, evident in the New Jersey case studies presented in this essay, illustrate both the opportunities and challenges that teachers, students, and supporters faced as they sought to expand women's institutional access to education. ${ }^{11}$ Through their efforts and examples, women across nineteenth-century New Jersey helped legitimate the place of educated women in society, assuring even greater educational opportunities to the generations of women that followed them.

\section{"A New World": The Age of Academies, 1780-1820}

The first half of the nineteenth century represented a true watershed moment in American women's access to education. A national preoccupation with the need for a well-educated citizenry, coupled with emerging middle-class values, contributed to families' increased support of education for both their sons and daughters. ${ }^{12}$ Along with their male counterparts, young women across the nation began to enjoy growing access to newly established academies, institutes and seminaries. By comparison, eighteenth-century women had only idiosyncratic and uneven access to formal educational opportunities, often limited to "dame schools" that taught young boys and girls how to read. After 1750, schools increasingly offered instruction in writing or drawing, but as scholar E. Jennifer Monaghan notes, there were more women in colonial America who could read but not

focus on women's entrance to elite "seven sister" colleges, and the need to examine other forms of institutional learning, including academies, seminaries, and co-educational institutions. Geiger also encouraged a more expansive approach to women's educational history. According to Geiger, women gained access to collegiate education decades before Vassar (1865) and Smith (1875) opened: "However defined, higher education for American women was a reality by the end of [the 1830s]" (183).

${ }^{10}$ Quotations from Mary W. Hale, “Comparative Intellectual Character of the Sexes," Godey's Lady's Book, and Ladies' American Magazine (New York), June 1840, 273; and Powers, Female Education, 8.

${ }^{11}$ While this essay presents a largely institutional history of women's education, it is important to note that learning also took place in several "informal" venues, including at home, in social circles, in reading groups, and in various societies and organizations established throughout nineteenth-century America. Most nineteenth-century women and men supplemented school attendance with a variety of self- and group-directed learning activities.

${ }^{12}$ For ideals about an educated citizenry in the early national period, see sources in note 3 above; for middle-class sensibilities and values, see C. Dallett Hemphill, Bowing to Necessities: A History of Manners in America, 1620-1860 (New York: Oxford University Press, 1999); Mary Ryan, The Cradle of the Middle Class: The Family in Oneida County, New York, 1700-1865 (New York: Cambridge University Press, 1981); and Opal, Beyond the Farm. 
write. Some elite women also attended "boarding" or "finishing" schools, where the emphasis was on acquiring polite accomplishments, rather than academic knowledge. Eighteenth-century women who developed strong intellectual lives, including the New Jersey poet Annis Boudinot Stockton, usually acquired education informally, often with the assistance of supportive male family members. ${ }^{13}$ After the American Revolution, women in all parts of the new nation benefited from a dramatic rise in the number and types of educational opportunities available to them.

An 1839 essay by noted educator Almira Lincoln Phelps (who, as we will see, played a part in New Jersey's educational history) attempted to trace the history of women's education as it had thus far developed in the United States. "So late as the beginning of the nineteenth century," she noted, "there was little opportunity for a female to acquire a liberal education." At that time, as Phelps lamented: "The only schools where females could resort, besides the common district school, were academies and boarding schools." Both boarding schools and academies operated under challenging conditions. These schools were funded almost exclusively by tuition, and typically relied upon a single teacher to provide instruction. Despite these similarities, there were important distinctions between these two types of institutions, and academies self-consciously attempted to improve upon the boarding school model. Promoters of academies criticized boarding schools for failing to provide a proper intellectual -- or moral -- environment. These schools, as Phelps charged, "were often mere nurseries of affectation and frivolity, where one person, and that one often wholly unqualified to instruct, would attempt to teach the various branches of education, together with the fashionable accomplishments of the day, as painting, embroidery, fillagree [sic] work and music." $" 14$

After the American Revolution, an "age of academies" began, offering young women their first true alternatives to boarding schools. ${ }^{15}$ Academies stressed academic

\footnotetext{
${ }^{13}$ For overviews of eighteenth-century women's education, see especially E. Jennifer Monaghan, "Literary Instruction and Gender in Colonial New England," American Quarterly 40 (1988): 18-41; and idem, Learning to Read and Write in Colonial America (Amherst, Mass: Massachusetts University Press, 2005); Jane Greer, ed., Girls and Literacy in America: Historical Perspectives to the Present (Santa Barbara: ABC-CLIO, 2003); Kevin J. Hayes, A Colonial Woman's Bookshelf (Knoxville: University of Tennessee Press, 1996); and Kenneth Lockridge, Literacy in Colonial New England: An Enquiry into the Social Context of Literacy in the Early Modern West (New York: Norton, 1974). For published primary sources containing evidence of eighteenth-century women's literacy, see Catherine LaCourreye Blecki and Karin A. Wulf, eds., Milcah Martha Moore's Book: A Commonplace Book from Revolutionary America (University Park, PA: Penn State University Press, 1997); Alice Morse Earle, ed., Diary of Anna Green Winslow: A Boston School Girl of 1771 (1894; reprint, Detroit: Singing Tree Press, 1970); Carol Karlsen and Laurie Crumpacker, eds., The Journal of Esther Edwards Burr, 1754-1757 (New Haven: Yale University Press, 1984); and Carla Mulford, ed., Only For the Eye of a Friend: The Poems of Annis Boudinot Stockton (Charlottesville: University of Virginia Press, 1995).

${ }^{14}$ Almira Lincoln Phelps, On Female Education (Rahway, NJ: 1839), 3. Phelps published this essay while serving as the Principal of the Rahway Female Institute in New Jersey. Phelps' essay provides a useful history of nineteenth-century women's education contextualized by the era's "separate spheres" ideology; the document also underscores how New Jersey's various contributions to women's educational history have remained "hidden in plain sight."

${ }^{15}$ For recent histories of female academies and other schools, see Beadie and Tolley eds., Chartered Schools; and idem, "Reappraisals of the Academy Movement," symposium introduction, History of Education Quarterly 41, no. 2 (2001), 216-229; as well as the individual essay in this symposium by Nancy
} 
accomplishment and a rigorous course of study. In an advertisement dated 1811, the trustees of the Female Academy in New Brunswick sought to distinguish themselves from a local boarding school, assuring patrons that their academy would provide "to young Misses a more accurate and extensive education than is usual."16 While the curriculum at individual female academies varied, most included instruction in reading, grammar, arithmetic, composition, geography, and natural philosophy. Some female academies also offered courses in Latin, botany, and chemistry. These schools modeled themselves on male academies established during the same time period, and some were co-educational. It was common, however, for many female academies to include "ornamental" offerings in music, drawing, painting and embroidery. These "ornaments" were considered necessary components of a woman's education, existing on a continuum with more academic subjects. Young women, for example, might paint or draw maps as a means of linking ornamental accomplishments to geography lessons. As scholars such as Margaret Nash and Mary Kelley argue, the overall curriculum offered at female academies was similar or equivalent to that of male academies established during the same period. ${ }^{17}$ A serious attention to academic study was the hallmark of most female academies established between 1780 and 1820.

Supporters of female academies regarded the education of women as a public, community enterprise that promoted the "literary and moral advancement of the country."18 Female academies, like their male counterparts, had Boards of Trustees or Examining Committees who visited the schools regularly and reported on their progress, providing a level of community oversight typically absent from the boarding school model. The support of prominent men helped legitimate female academies and reinforced the importance of women's education. Further modeling the practices at male schools, female academies held regular "examinations" or "exhibitions," in which the students"

Beadie entitled, "Academy Students in the Mid-Nineteenth Century: Social Geography, Demography, and the Culture of Academy Attendance," 251-262. For a general overview of the "age of academies," see Theodore Sizer, ed., The Age of Academies (New York: Teachers College, Columbia University, 1964). ${ }^{16}$ See various advertisements for the "Female Academy," The Guardian (New Brunswick, NJ), April 18, 1811; May 2, 1811; and The Fredonian (New Brunswick, NJ), May 21, 1812; and May 28, 1812. The Female Academy was established sometime during the first decade of the nineteenth century. The first advertisements for the Female Academy that I have been able to locate in extant New Brunswick newspapers date from 1811; yet evidence from Rachel Van Dyke's journal suggests that she began attending the academy in 1807 (see her February 28, 1811 journal entry, cited in note 21 below). In addition, Ebenezer Grosvenor's journal, dated April-May 1808, indicates that he was an instructor at a "school of young misses" in New Brunswick during this time. See Lucia McMahon and Deborah Schriver, eds., To Read My Heart: The Journal of Rachel Van Dyke, 1810-1811 (Philadelphia: University of Pennsylvania Press, 2000), especially 360-70 for a full transcription of Grosvenor's 1808 journal.

${ }^{17}$ For the importance of ornamental subjects, see Catherine E. Kelly, "Reading and the Problem of Accomplishment," in Heidi Brayman Hackel and Catherine E. Kelly, eds., Reading Women: Literacy, Authorship, and Culture in the Atlantic World, 1500-1800 (Philadelphia: University of Pennsylvania Press, 2008), 124-143; and Margaret Nash, "“A Triumph of Reason': Female Education in Academies in the New Republic," in Beadie and Tolley, eds., Chartered Schools, 64-86. As Nash points out, training in needlework and sewing provided necessary skills for most women's domestic duties at home, as well as practical vocational training for women's potential employment as seamstresses. For discussion of the similarities in male and female curricula, see Kelley, Learning to Stand and Speak; and Nash, Women's Education in the United States.

18 "Education," The Portfolio (Philadelphia), April 17, 1802, 116. 
progress could be measured and displayed to the larger community. Accounts of these ceremonies were printed in early national newspapers and periodicals so the public could keep track of women's educational progress. An 1805 newspaper article noted that the young women's performance at the Trenton Academy's "quarterly examinations" was "honorable to themselves and creditable to their instructor and to the institution." In 1811, the trustees of the Female Academy in New Brunswick praised "the great improvements made by the young ladies, during the last session, as exhibited at their examination." 19

The experiences of Rachel Van Dyke, a student who attended the Female Academy in New Brunswick, illustrate how academies transformed women's educational experiences. Born in 1793, Rachel was the daughter of Frederick Van Dyke, a merchant and farmer, and his wife Lydia. Like many middling- and elite families of the time, the Van Dykes supported the educational pursuits of both their sons and daughters. Rachel's older brother Augustus graduated from the College of New Jersey in Princeton, and then studied medicine with Dr. Benjamin Rush at the University of Pennsylvania in Philadelphia. As a girl, Rachel attended Miss Hay's Boarding School in New Brunswick, and later enrolled at the Female Academy, led at the time by a Mr. Preston.

At the Female Academy, Rachel and her classmates were taught a rigorous course of study by college-educated men who brought with them enlightened ideas about the intellectual capacities of women. When Ebenezer Grosvenor began teaching at the academy, Rachel was pleased to discover that his "sentiments on the female sex" were "generous in the extreme." Rachel's ability to attend a female academy transformed her sense of self, despite the occasional criticism she received from those who remained skeptical about the benefits of women's education. She complained in her journal about those who asked: "Why how long are you going to school? ... . When will you finish your education? They think that I knew how to read and write a long time ago and wonder what I can be learning all this time." Poorly educated women who "talk of nothing but dress, amusements, the beaux, and such like nonsense" also angered Rachel. ${ }^{20}$ Determined to set herself apart from "such girls as these," Rachel continued her studies at the female academy, including a special Latin class led by Grosvenor, and surrounded herself with men and women who supported her ardent pursuit of education. Reflecting on her educational experiences on her eighteenth birthday in 1811, Rachel noted:

It is about four years since Mr. Preston taught school here, and from that time I date my improvement. Then I knew nothing about Grammar, Geography,

\footnotetext{
${ }^{19}$ The Miscellany (Trenton, NJ), September 16, 1805; and various advertisements for the "Female Academy," The Guardian (New Brunswick, NJ), April 18, 1811; May 2, 1811; and The Fredonian (New Brunswick, NJ), May 21, 1812; and May 28, 1812.

${ }^{20}$ McMahon and Schriver, eds., To Read My Heart, see journal entries dated July 17, 1810; June 20, 1810; and July 24, 1810. Miss Hay's boarding school remained in operation through most of the 1810s, even after the establishment of the Female Academy in New Brunswick. An advertisement for Miss Hay's appeared in The Fredonian (New Brunswick, NJ), April 20, 1815. For an overview of New Brunswick women's educational opportunities, see Mary Demarest, "Some Early New Brunswick Schools for Girls," Proceedings of the New Jersey Historical Society 53:3 (July 1935): 163-185.
} 
Arithmetic, Composition or anything else. My studies were never explained to me, I did not understand them, never felt myself interested, and thought if I repeated them (like a parrot) correctly, it was sufficient. I went to Mr. Preston. A new world opened to me; and I improved more in one quarter under his tuition, than I had done for many years with Miss Hay. ${ }^{21}$

As families sought to provide young women with "a new world" of educational opportunities, female academies became increasingly popular. In 1813, another New Jersey woman echoed Rachel Van Dyke's concerns about the quality of education available to her nieces at Miss Hay's boarding school: "I cannot feel altogether satisfied with the plan of sending them to Miss Hay, she even considered herself incompetent to teaching Grammar and Geography." Even those families who opted to send their daughters to boarding schools emphasized the importance of rigorous attention to academic study. When her daughter attended Miss Hay's school in 1813, Maria Cornell hoped that proper attention to education would prevail: "I hope it is favorable for the purposes of study and improvement - and that you will be diligent - make this opportunity the harvest of your mind." Ultimately, families hoped that access to education would train young women to become useful and accomplished members of early national society. John Cornell encouraged his daughter to "attend to the various branches of improvement not as a task - but with a view to advance your future comfort and usefulness in the world. ${ }^{, 22}$

The Newark Female Academy and Newark Institute for Young Ladies illustrate these links between the education of women and their future "usefulness in the world." The Newark Academy traced its roots back to the eighteenth century, although the school suspended its operation during the Revolutionary war. The school reopened in 1782, and a new building was completed in 1792. During this time, advertisements suggest that it was exclusively a male academy, but historian Suzanne Geissler has uncovered evidence that at least one young woman attended the institution in 1798. In 1802, "a female academy and boarding school" was added to the Newark Academy, operated and supervised "under the patronage and inspection of the trustees." William Woodbridge was hired as the principal of the Newark Female Academy. Woodbridge had attended Yale College, had experience as a teacher in New England, and was praised for his "uncommon reputation as a teacher and instructor of youth." 23

The Newark Academy issued a broadside announcing the establishment of its new female academy, which was reprinted in the Portfolio, Joseph Dennie's famous periodical published out of Philadelphia. "Having taken into consideration the high importance of female education," and eager to "promote the interest of society," the Newark Female

\footnotetext{
${ }^{21}$ McMahon and Schriver, eds., To Read My Heart, journal entry dated February 28, 1811.

${ }^{22}$ Catherine Frelinghuysen to Maria Cornell, March 27, 1813; Maria Cornell to Margaretta Cornell, May 17, 1813; and John Cornell to Margaretta Cornell, August 8, 1814, Frelinghuysen-Cornell Family Papers, Special Collections, Alexander Library, Rutgers University, New Brunswick, NJ.

23 "Education," The Portfolio (Philadelphia), April 17, 1802, 116. For historical accounts of the Newark Academy, see Suzanne Geissler, A Widening Sphere of Usefulness: Newark Academy, 1774-1993 (West Kennebunk, MA: Phoenix Publishing, 1993); and Robert Lentz, ed., Beams of That Sun: Two Centuries at the Newark Academy (Livingston, NJ: The Newark Academy, 1976).
} 
Academy promised to provide academic excellence to its students. As the broadside indicated, students would be examined each quarter "with respect to their progress in their several studies, in the presence of the Trustees . . . and such ladies and gentlemen, as, by invitation shall attend on the occasion." 24 The Newark Academy's decision to hold quarterly examinations was practiced at many female academies throughout the nation. The Young Ladies' Academy of Philadelphia and Susan Rowson's academy in Massachusetts held similar ceremonies. ${ }^{25}$ Published accounts of these events appeared in various newspapers, periodicals, and pamphlets, serving as testimony to the "high importance" placed on women's education during the critical years of nation building. In 1803, extracts from the Newark Academy's trustees' meeting were published in the Gazette of the United States. The trustees invited educator Isabella Graham to attend the examination, who expressed her approval of the students' performance in "reading, writing, grammar, geography, and ciphering." Graham framed her support of the students' progress in terms that reinforced the larger aims and ideals of women's education (Figure 1). "For the happiness of my sex, the benefit of the community, and the good of the succeeding generations," she noted, "I sincerely wish every proper encouragement given to your laudable institution.",26

During the first decade of the nineteenth century, while the Newark Academy was the subject of such public praise, at least some instruction was co-educational. Yet in 1809, a formal decision was made by the Board "that it is expedient that the Academy be divided into two departments, the one for the instruction of Young Ladies and the other for Boys." This decision may have reflected a bias against co-educational education (although it was commonly practiced in several New England schools at the time); or may have represented an effort by the Newark Academy to capitalize on the success enjoyed by other well-regarded female academies. In 1810, Timothy Alden was hired to head the "young ladies' department," along with Prudence Williams, who served as "preceptress" of the academy. A Harvard graduate, Alden was a Congregational minister who had previously taught at female academies in Portsmouth and Boston. ${ }^{27}$

\footnotetext{
24 "Education," The Portfolio (Philadelphia), April 17, 1802, 116.

${ }^{25}$ For examples of printed accounts of ceremonies conducted at female academies, see The Rise and Progress of the Young Ladies' Academy of Philadelphia: Containing an Account of the Number of Public Examinations and Commencements; the Charter and Bye-Laws; Likewise, A Number of Orations Delivered by the Young Ladies, And Several by the Trustees of Said Institution (Philadelphia: Printed by Stewart \& Cochran, 1794); Susanna Rowson, A Present for Young Ladies (Boston: John West \& Co, 1811); and Charles Stearns, Dramatic Dialogues for the Use of Schools (Leominster, MA: John Prentiss, 1798). For further description and analysis of these ceremonies, see Kelly, "Reading and the Problem of Accomplishment;" Nash, Women's Education in the United States; and Opal, Beyond the Farm.

26 "Newark Academy," Gazette of the United States (Philadelphia), May 20, 1803.

${ }^{27}$ Quoted in Geissler, A Widening Sphere of Usefulness, 61-62; also see Timothy Alden, Key to Quarterly Catalogues of the Names of the Young Ladies at the Newark Academy: Under the Instruction of Rev. Timothy Alden; with a Historical Sketch of the Academy (Newark: William Tuttle, 1810), 10-11. For the Newark Academy's co-educational history, see A Widening Sphere, especially pages 11, 26, 46, and 55.
} 


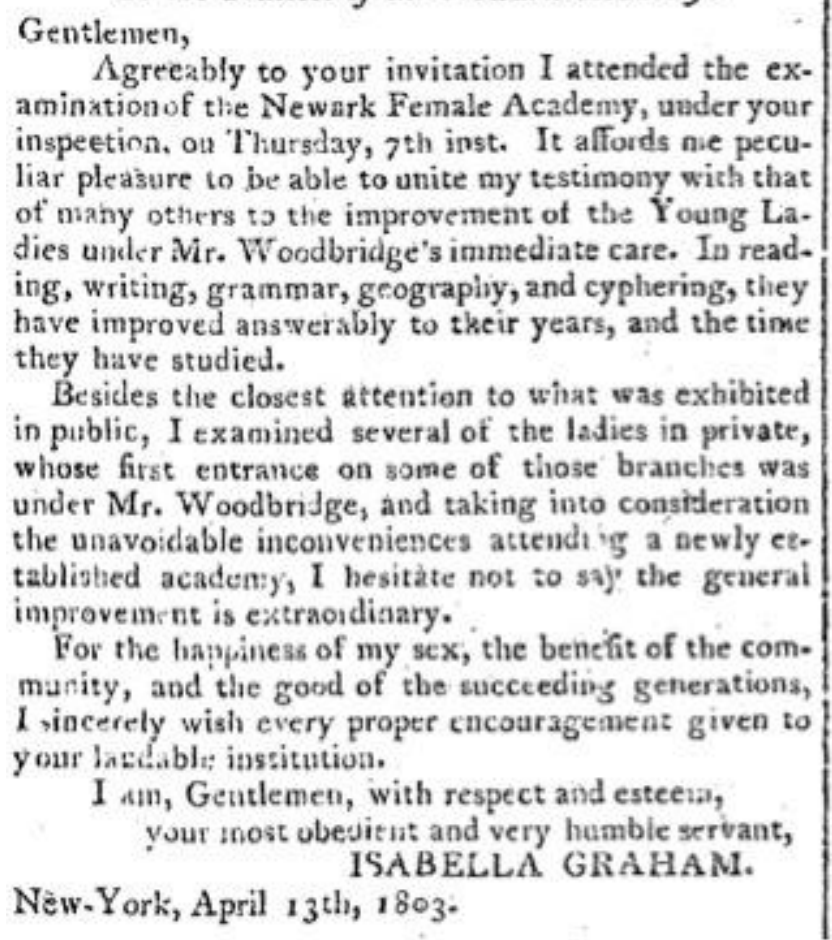

Figure 1. "To the Trustees of the Newark Academy." Published letter of Isabella Graham, dated April 13, 1803. Gazette of the United States, May 20, 1803. Available online through Nineteenth Century

$$
\text { Newspapers database. }
$$

Alden assured prospective patrons that "all branches useful and ornamental, are taught, by various instructers, which are deemed important at any institution in the United States." Young women attending the Newark Academy studied a basic course of "common sewing, writing, arithmetick, English grammar, and the principles of morality and religion" at five dollars a quarter (this was equivalent to the tuition for young men pursuing the academy's "English school" curriculum). Young women could also pursue advanced work in geography, astronomy, history, composition, natural philosophy, as well as courses in needlework, embroidery and painting, for eight dollars a quarter. French, music, and dancing were available for a separate fee. Students from out of town who boarded with Mr. Alden's family were charged a total of fifty dollars per quarter, although young women attending school away from home often boarded with relatives or friends. ${ }^{28}$

As Alden reminded his students, their pursuit of knowledge "will render you a comfort to your relatives, an honour to this institution, a blessing to the world, and the glory of your

\footnotetext{
${ }^{28}$ Alden, Key to Quarterly Catalogues, 11-12; Geissler, A Widening Sphere of Usefulness, 63-64. The costs at the Newark Academy and other New Jersey female academies were on par with most academies founded during the early nineteenth century. See Nancy Beadie, "Internal Improvement: The Structure and Culture of Academy Expansion in New York State in the Antebellum Era, 1820-1860," in Beadie and Tolley, eds., Chartered Schools, 100.
} 
sex." ${ }^{29}$ A woman's educational progress reflected not only on her individually, but also on the institution she attended, the community she lived in, and the status of women as a sex. To encourage these lofty efforts, Alden printed a "Quarterly Catalogue" of all students who attended the Newark Academy. Beside each student's name was a complicated set of numbers and initials that indicated her standing and progress in the academy's main subject areas. In the first twelve-week quarter under Alden's direction, Eliza Pintard Boudinot recited 240 lessons, wrote 36 compositions, and received 11 certificates of merit. Her classmate Ann Clay Wallace was equally productive, and recited 240 lessons, wrote 32 compositions and received 12 certificates. Students who excelled in composition had their pieces exhibited at the academy's examinations and received commendations in the quarterly catalogues. Catherine Gouverneur Odgen was commended for having "written abundantly more, ... than any other young lady in this institution, and in a style superior to that of any other." Pieces of embroidery and painting also were exhibited and noted in the catalogues. The decision to list these young women's names and achievements in published catalogues reflected the public nature of women's education in the early national period. This public notice was a deliberate effort to call attention to the important work undertaken at the academy, as well as to inspire continued academic achievement in students: "These have been deliberately affixed to your names, with a vie to stimulate a laudable ambition., ${ }^{30}$

Once students "finished their academical education," they received a "VADE MECUM" which Alden hoped would serve "as a token of his best wishes, and a friendly remembrancer on the journey of life." The graduates of the Newark Academy in March 1811 included:

Elizabeth Pintard Boudinot, Newark
Maria Matilda Cumming, Newark
Maivina Forman, Newark
Rivine Forman, Newark
Tace Bradford Hillyer, Orange
Elizabeth Alison Mercer, Cincinnati
Margaret Chatham Seth, Rhinebeck
Jeanet Smith, New York
Elizabeth Jane Smith, Newark
Ann Julia Stockton, Princeton
Jane Ten Brook, Newark
Anny Clay Wallace, Newark

As this list indicates, daughters from New Jersey's most respected families attended the Newark Academy. Many students were residents of Newark, but young women traveled

\footnotetext{
${ }^{29}$ Timothy Alden, Newark Academy, New Jersey. Young Ladies' Department, Under the Care of the Rev. Timothy Alden (Newark: William Tuttle, 1809), 31.

${ }^{30}$ See Timothy Alden, Key to Quarterly Catalogues, 3-8; and idem, Quarterly Catalogue of the Names, with Various Honorary Notices, of the Young Ladies, Who Belong to the Newark Academy, Under the Instruction of Rev. Timothy Alden (Newark: William Tuttle, 1810-1812), 4, 14, 83 (and throughout for evidence of student achievement).

${ }^{31}$ Alden, Quarterly Catalogue, 39-40.
} 
from various New Jersey towns, as well as from New York, Massachusetts, Delaware, and Pennsylvania, to attend the academy. During Alden's two years at the Newark Academy, approximately 125 young women attended the school. The history of the academy in the years immediately following Alden's departure is not clear. His successor, Samuel Whelpley, resigned in 1814, and the school's reputation may have suffered due to repeated turnovers. ${ }^{32}$ By 1825 , when the school began attracting public notice again, it had been renamed as the Newark Institute for Young Ladies. Both the school's new name and curriculum reflected evolutions in the education of women. The "age of academies" was ending, and a new era was on the horizon.

\section{"Intellectual Pioneers": Seminaries and Institutes, 1820-1840}

Between 1780 and 1820, academies dramatically improved women's institutional access to education. Although some of these schools were in operation for only a few years, others enjoyed decades of success. An individual academy's success (or failure) often rested in the hands of its main teacher. When favored teachers resigned, it could be difficult, as the Newark Academy experienced, to hire and retain suitable replacements. Educators began to recognize the need for more permanency and systemization in women's education. Emma Willard's petition to the New York State Legislature in 1818 to request state funding for female seminaries marked the beginning of a new era in women's education. ${ }^{33}$ By the late 1820 s, female "academies" gave way to "seminaries" and "institutes," as educators sought to ensure permanency for their institutions and to achieve further parity between women and men's education. ${ }^{34}$

\footnotetext{
${ }^{32}$ See Alden, Quarterly Catalogue, 63, and 78-82 for a list of all students (and their residences) who attended the academy under his supervision. For the school's history after Alden's departure, see Geissler, A Widening Sphere of Usefulness, 69-78.

${ }^{33}$ Emma Willard, An Address to the Public: Particularly to the Members of the Legislature of New York, Proposing a Plan for Improving Female Education (Middlebury: Printed by J. W. Copeland, 1819). For background information on Willard and her Troy Female Seminary, see Nancy Beadie, "Emma Willard's Idea Put to the Test: The Consequences of State Support of Female Education in New York, 1819-67," History of Education Quarterly 33, no. 4 (1993): 543-62; Anne Firor Scott, "The Ever Widening Circle: The Diffusion of Feminist Values from the Troy Female Seminary, 1822-1872," History of Education Quarterly 19, no. 1 (1979): 3-25; and idem, "What, Then, is the American: This New Woman?" Journal of American History 65 (1978): 679-703; and Lucy Forsyth Townsend, "Emma Willard: Eclipse or Reemergence?" Journal of the Midwest History of Education Society 18 (1990): 279-92.

${ }^{34}$ Scholars often use various terms interchangeably when discussing schools for women, including boarding schools, venture schools, dame schools, academies, and seminaries. There are important distinctions between these terms; Kim Tolley provides some working definitions that both clarify and confuse the issue. Tolley uses the term venture school to refer to "an institution supported entirely by tuition" (20). As a result, Tolley characterizes many early female academies as venture schools, even though most of these schools were advertised as and explicitly referred to as academies by their founders. By contrast, Tolley defines an academy as an institution "legally incorporated to ensure financial support beyond that available through tuition alone." (21). Because she sets financial organizing as the key defining characteristic, Tolley continues to use the terms academy, seminary, and institute interchangeably. Tolley suggests that "there are no clear institutional differences to help scholars distinguish" between female academies and seminaries (22). I disagree, and suggest that there are important pedagogical and philosophical distinctions between these types of institutions. In particular, the distinctions are reflected chronologically: female academies were established largely before the 1820s; in the 1820s-1840s, more schools began referring to themselves as seminaries or institutes. Thus, Tolley's primary emphasis on financial backing ultimately may limit how we define and analyze the variety of schools established for
} 
The emergence of seminaries and institutes was more than just a matter of semantics: it reflected a change in how educators envisioned the form, function, and even funding of their institutions. The shift in language signified a renewed attention to women's education, even though, as Emma Willard understood, the idea of "sending ladies to college" was still considered an "absurdity.",35 Yet as Almira Phelps (Figure 2) emphasized in her 1839 essay, seminaries and institutes had explicit, self-conscious aims to transform women's education:

The establishment of female seminaries, or institutions of a permanent and elevated character, uniting teachers of varied talents under the direction of a Principal of experience and wisdom, must be regarded as a most important step in female education. Here, a regular system of instruction may be pursued. ... .Seminaries of this kind are fast multiplying in our country; they are not only the nurseries of female talent, but to those of the sex who are capable of teaching others, afford stations of dignity and usefulness. It may seem arrogant in Americans to say it, but it is true, and a conviction of this truth may serve to encourage us in our efforts - Europe is now looking to us as pioneers in female education. ${ }^{36}$

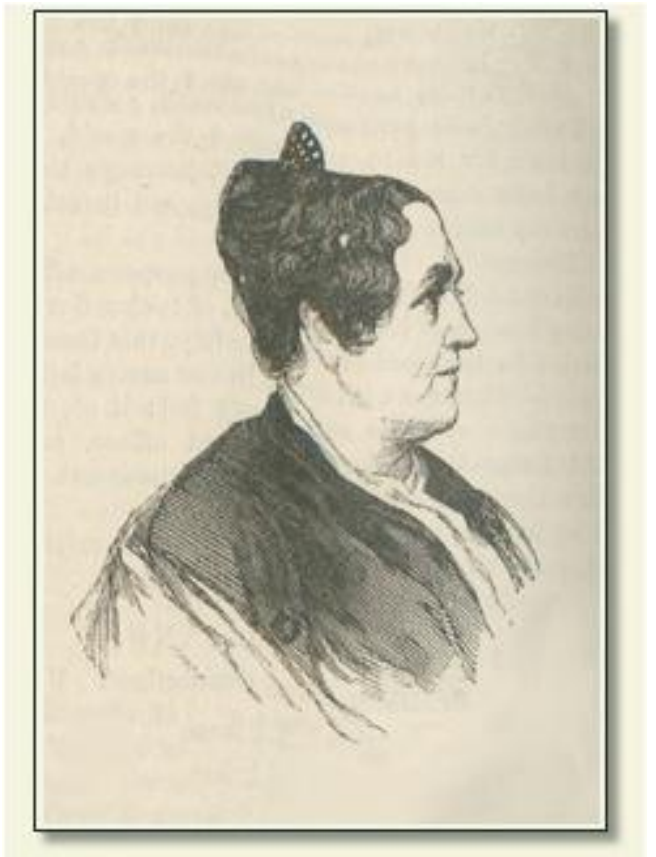

Figure 2. From online exhibit: "Portraits of American Women Writers," Library Company of Philadelphia: http://www.librarycompany.org/women/portraits/phelps_almira.htm

women in the nineteenth century. By attempting to apply the same defining standards to both male and female institutions, Tolley may inadvertently be obscuring particular distinctions and evolutions that marked the history of women's education. See Kim Tolley, "Mapping the Landscape of Higher Schooling, 1727-1850," in Beadie and Tolley, eds., Chartered Schools, 19-38.

${ }^{35}$ Willard, An Address to the Public, 5.

${ }^{36}$ Phelps, On Female Education, 4. Emphasis in original. 
Seminaries and institutes built upon the success achieved during the age of academies while pursuing "elevated" goals. While seminaries and institutes relied primarily on tuition for funding, many of these schools incorporated and sought endowments. ${ }^{37}$ Willard and other educators also continued to petition for state funding for women's education. Seminaries developed three- or four-year curricula that emphasized more systematized, regimented courses of study. Many seminaries began to offer diplomas or other certificates to indicate a completed course of study, adding weight and respectability to their institutions. Unlike academies, which typically relied upon one teacher's efforts, seminaries employed several instructors who taught specialized subjects. A principal supervised school operations, and a Board of Trustees or Examining Committee typically attended examinations to provide further oversight. By the 1840s, many seminaries had begun to offer women collegiate courses of study, although most followed Willard's lead and self-consciously avoided designating themselves as colleges. $^{38}$

The Newark Institute for Young Ladies reflected these emerging shifts in the naming, curriculum, and philosophy of schools for women. In 1825, the Newark Institute was run by J. Livingston Van Doren and his father Rev. Isaac Van Doren. Three female teachers and a male professor of languages assisted the Van Dorens. Distinguished gentlemen, including James Milnor and Theodore Frelinghuysen, served on the school's Examining Committee. The school offered a first and second course of study, which together comprised a four-year curriculum. By their fourth year, students engaged in an extensive course of study that included lectures in "natural and experimental philosophy and astronomy," chemistry, botany, and geology. The school was "furnished with a Philosophical and Chemical Apparatus, and Cabinet of Minerals," and boasted an "extensive assortment" of maps, globes, and copper-plate engravings. The "Class in Astronomy" had the use of "one of the largest and most perfect reflecting Telescopes in the country." While the Newark Institute promoted scientific study, it did not neglect courses in grammar, rhetoric, composition, and elocution. All students were required to keep journals and to write weekly compositions, which were "to be read before their respective classes, subject to the criticism of the class and teacher." 39

\footnotetext{
${ }^{37}$ For information on the funding, incorporation, and endowment of schools for women, see Tolley, "Mapping the Landscape of Higher Schooling," in Beadie and Tolley, eds., Chartered Schools, 19-38.

${ }^{38}$ The fact that most female seminaries and institutes did not refer to themselves as colleges at this time, even as they often promoted the "collegiate" level of their curriculum, suggests that schools for women thought carefully about how to name and advertise themselves. This supports the idea that the shift from academies to seminaries and institutes was rooted in more than just semantics, and reflected a selfconscious, deliberate move towards redefining the nature of women's education at a time when college for women still seemed too radical.

${ }^{39}$ See Powers, Female Education, and a pamphlet advertising the school, Newark Institute for Young Ladies (Newark: 1826). Also see advertisement for the "Newark Institute for Young Ladies," New York Spectator, April 22, 1825. The Newark Institute's curriculum reflected two trends that marked nineteenthcentury women's education: an increasing emphasis on scientific studies for women, and a concern with composition and rhetoric. For women and science, see Nina Baym, American Women of Letters and the Nineteenth-Century Sciences (New Brunswick: Rutgers University Press, 2002); and Kim Tolley, "Science for Ladies, Classics for Gentlemen: A Comparative Analysis of Scientific Subjects in the Curricula of Boys' and Girls' Secondary Schools in the United States, 1794-1850," History of Education Quarterly 36,
} 
The Newark Institute recognized that its approach to women's education had radical implications, and sought public support. At the school's first anniversary ceremony in 1826, Rev. Henry Powers delivered his address on female education, in which he stressed three main themes: "the value of intellectual attainment; the defectiveness of female education; and the importance and feasibility of improving it." Powers argued that the "prevailing system of female education is in so many respects defective," and hoped that schools such as the Newark Institute would provide the remedy. Yet proponents of women's education had to walk a fine line between encouraging women's ardent intellectual pursuits and simultaneously reassuring the public that the status quo would otherwise remain unchanged. Despite its rigorous curriculum, Powers insisted that the Newark Institute had no desire to "confound all distinction between the intellectual pursuits of the sexes." Rather, Powers argued that women be allowed to study "those attainments most proper for their station, and best suited to their powers." 40 At the time, women's proper station consisted of family and social circles; benevolence and reform work; and for an increasing number of women, teaching and writing. Promoters understood that public support of female education rarely translated into a belief in women's political or economic equality.

While reassuring patrons that educated women would remain in their proper "sphere of action," Powers delineated the Newark Institute's philosophy in ways that emphasized a strong support of women's education. The work the Newark Institute hoped to accomplish was a "bold experiment" that required intellectual prowess and creativity: "We are a kind of intellectual pioneers, to whom it belongs to strike out the course." Powers argued that women and men needed to be "partners in the pursuit and cultivation of knowledge," and urged the public to support women's education. Male support was critical to the success of many schools for women, but ultimately the true test of any institution's success rested in its pupils. At the end of his address, Powers urged the young women attending the Newark Institute to take pride in their intellectual accomplishments: "Demonstrate to a mistaken world, that you are competent to those sciences which expand, exalt, and dignify." "41 The Newark Institute for Young Ladies was re-inventing the Newark Female Academy, and urged its students to recognize the important intellectual and social work represented by this "bold experiment."

At its first anniversary ceremony, the Newark Institute continued the common practice of holding public examinations, administered "by a Select Committee of the Literary Gentlemen from different parts of the country." To underscore its new educational

no. 2 (1996): 129-53. For composition and rhetoric, see Jean Ferguson Carr, Stephen L. Carr, and Lucille M. Schultz, Archives of Instructions: Nineteenth-Century Rhetorics, Readers, and Composition Books in the United States (Carbondale: University of Illinois Press, 2005); Janet Carey Eldred and Peter Mortensen, Imagining Rhetoric: Composing Women of the Early United States (Pittsburgh: University of Pittsburgh Press, 2002); and Lucille Schultz, The Young Composers: Composition's Beginnings in Nineteenth-Century Schools (Carbondale: University of Illinois Press, 1999).

${ }^{40}$ Powers, Female Education, 3-8.

${ }^{41}$ Powers, Female Education, 11-18. 
philosophies, the Newark Institute also began issuing diplomas "with the signatures of the Principals, Teachers, and Examining Committee." The public took notice of the Newark Institute's efforts, especially its public ceremonies. As an anonymous reviewer of Powers' address noted: "An annual examination is held, and certificates are issued, which somewhat resemble collegiate degrees." As this author understood, the Newark Institute's decision to emulate a "collegiate" course of study, including its commencement ceremonies, was a deliberate means of creating equity between men's and women's education: "Those anniversaries have given a powerful impulse to our learned foundations for the education of young men, and why should not a similar effect by produced in establishments for the culture of female intellect?" Approving of the Newark Institute's goals, this author wished the school "full success in the laudable attempt to give to the public a practical demonstration of the truths taught in [Powers'] address." 42

The Examining Committee of the Newark Institute for Young Ladies also issued a favorable report, after witnessing the students' achievements during their examinations:

[We] congratulate the Board on the prospect of the Institute's becoming equal in character with any other in the United States. During several years, the Academy has been without any regular Principal of this department, in a declining state; a new era has now commenced: Under the present system, a regular female collegiate course is pursued; Professors of Languages and of the Sciences of Natural and Experimental Philosophy, Chemistry, Botany, \&c. are procured, and nothing neglected that may be necessary to complete a Lady's Education, and make her accomplished, respected, and useful in any sphere of life..... We owe it to ourselves and children, to patronize an Institution so worthy of our support, and in whose welfare our moral and literary reputation, as a highly favored town, are intimately connected. ${ }^{43}$

The Newark Institute played a leading role in promoting a "new era" in women's education, and indeed, was one of the first institutes in the nation to refer to its course of study as "collegiate." Its teachers, trustees, and examining committee promoted the cause of women's education in strong, unapologetic terms. By publishing Powers' address on education, the Newark Institute kept the subject of women's education squarely in the public eye, hoping to achieve national prominence ("equal in character with any other in the United States") for its important work.

Despite public attention and support, the school's principals, the Van Dorens, left the Newark Institute in December 1827 in order to establish a school for young women in Brooklyn, New York. The Newark Institute struggled to replace the Van Dorens, but remained in operation. By 1832, the school flourished again, under the direction of Leonard and Susan Worcester. Approximately eighty students per term enrolled at the Newark Institute during the 1830s. While most of the young women were from Newark, students from Bloomfield, Orange, Hanover, Parsippany and New York also attended.

\footnotetext{
${ }^{42}$ The Evangelical Witness, September 1, 1826, 397-408.

43 "Report of the Examining Committee," printed in Powers, Female Education, 22.
} 
The school was divided into Introductory, Junior and Senior departments, and the course of study remained on par with "the most approved modern Seminaries."44

New Jersey women were not limited to educational opportunities available in their own state, and also enrolled at various schools in New York, Pennsylvania, and New England. Since the 1790s, New Jersey families from New Brunswick, Newark, Elizabethtown, and other towns had sent their daughters to the well-respected Moravian Seminary for Young Ladies in Bethlehem, Pennsylvania. Between 1792 and 1833, seventeen students from New Jersey attended Sarah Pierce's famous academy in Litchfield, Connecticut. In 1828, a young woman by the name of Louisa E. Vancleve from Princeton enrolled as a student at Troy Female Seminary; in time numerous New Jersey women joined her. In 1842, seven young women from New Jersey attended Mount Holyoke; a decade later, twenty women from a variety of New Jersey towns had traveled to Massachusetts to enroll as students. ${ }^{45}$

Some New Jersey women followed the Van Dorens to Brooklyn. Incorporated in 1829, the Brooklyn Collegiate Institute for Young Ladies modeled much of its curriculum and structure on the Van Dorens' earlier efforts at the Newark Institute. Their name for the new school, a collegiate institute, reflected a more explicit recognition of the rigorous curriculum offered. As its catalogue noted: "The Collegiate Institute is designed to afford facilities to females in acquiring an education, corresponding with those enjoyed by the other sex in our colleges." 46 By 1831, 175 pupils had enrolled at the Brooklyn Collegiate

\footnotetext{
${ }^{44}$ See Catalogue of the Officers, Teachers, and Pupils of the Young Ladies' Institute in Newark, N.J., for the Session Ending August 3, 1833 ([Newark]: Henry H. Hassey, Printer, 1833). An 1832 advertisement assured patrons that "every branch of a finished and useful education is taught in this institution." See "Newark Institute," Philadelphia Album and Ladies' Literary Portfolio, March 31, 1832; and Geissler, A Widening Sphere of Usefulness, 79-81. By this time, the Newark Institute also faced increasing competition from other schools established in Newark. Advertisements for the "Washington Academy," led by A. J. Ankrim, and the "Young Ladies' English and French Seminary," run by J. A. Grant, appear in various issues of the Newark Daily Advertiser (see, for example, March 11, 1833, March 12, 1833, March 16, 1833, and April 16, 1833).

${ }^{45}$ Evidence of New Jersey women's attendance at out-of-state schools can be found in various school catalogues, including William H. Bigler, A History of the Rise, Progress, and Present Condition of the Moravian Seminary for Young Ladies, at Bethlehem, PA with a Catalogue of its Pupils, 1785-1858, $2^{\text {nd }}$ Edition (Philadelphia: J. B. Lippincott \& Co, 1874); Catalogue Of The Members Of The Troy Female Seminary; For The Academic Year, Commencing September 17, 1828, And Ending August 5, 1829, Together With The Conditions Of Admittance, \&c. (Troy: Francis Adancourt, Printer, [1828?]); Mary J. Mason Fairbanks, ed., Emma Willard and Her Pupils: Or, Fifty Years of Troy Female Seminary, 1822 1872 (New York: Mrs. Russell Sage, 1898); Sixth Annual Catalogue of the Mount Holyoke Female Seminary, in South Hadley, Mass. $1842-43$ (Amherst: J. S. \& C. Adams, Printers, 1843); Sixteenth Annual Catalogue of the Mount Holyoke Female Seminary, in South Hadley, Mass. 1852-1853 (Springfield, Mass: Printed by Horace S. Taylor, 1853). For New Jersey women at the Litchfield Academy, see Brickley, "Sarah Pierce's Litchfield Female Academy," 60.

${ }^{46}$ See Prospectus of the Brooklyn Collegiate Institute for Young Ladies (Brooklyn: [1830?]; and Brooklyn Collegiate Institute for Young Ladies; Brooklyn-Heights, Opposite the City of New York (Brooklyn Heights, 1830). The Brooklyn Institute caught the attention of various New York publications. See "Collegiate Institute for Young Ladies," The Albion (New York), November 21, 1829; "Brooklyn Collegiate Institute, for Young Ladies," Euterpeiad (New York), August 16, 1830; New York Herald, May 1, 1830; also see "Academies, High Schools, Gymnasia," Quarterly Register of the American Education Society (Boston), May 1831, which reported that the Brooklyn Collegiate Institute was "designed to afford young ladies the
} 
Institute, including a young New Jersey woman named Aletta Van Dunk. In her first journal entry, dated May 12, 1828, Aletta expressed regret and ambivalence about leaving the comforts of her Somerville home to attend school in Brooklyn: "I acknowledge I did not feel much pleasure at the thought of spending the summer from home but when I saw the great importance of it I consented." Despite Aletta's feelings of homesickness, her journal soon began to reflect a sense of duty and obligation to her studies: "May I ever find myself gaining more knowledge every day and as I ascend the urged hill of science $\mathrm{O}$ may nothing occur to persuade me to deviate from the road till at last may I be possessor of that happiness to which there is no end!" Aletta's journal entries on education (which, it should be noted, were read by her instructors and most likely shared with her classmates) reflected prevailing ideas about the need to educate women properly: "I think it would afford my dear Parents and friends no small degree of pleasure to find me gaining the knowledge which will be a source of everlasting happiness to me and those with whom I associate."

Aletta's journal also sheds light on school examinations. These events were attended by the examining committee as well as by family and community members. Published accounts of ceremonies also allowed individuals to read about the intellectual accomplishments of female students. As Aletta noted, some students were nervous at the prospect of such public scrutiny: "As the approach of the examination daily becomes nearer, and the dread we felt for it, increased as every hour was announced, I endeavoured to apply myself with diligence to my studies, that I might be enabled to bear the scrutiny of the committee." Hoping to make a good impression with the examining committee, some students worried that they were not prepared sufficiently for the rigorous examinations. As Aletta remarked, these ceremonies were tests of character as well as intelligence: "Alas! If we shrink from the scrutiny of man, how shall we appear before God?" After the ceremony, Aletta reported that she "was happily No. 1 in Industry \& Behaviour." 48 Her pride at receiving these honors suggests that these examinations despite the "dread" they caused some students -- motivated young women to pursue their studies ardently.

As Aletta advanced in her studies, she continued to develop strong feelings about the importance of women's education. In her journal entry for November 18, 1829, she mused about women's untapped intellectual potential:

same advantages as are afforded at Colleges to the other sex." In 1835, the New York Spectator reported that the Van Dorens had left New York and established the "Van Doren's College for Young Ladies" in Lexington, Kentucky. See New York Spectator, February 23, 1835.

Little attention has been paid to these collegiate institutes, yet evidence suggests that these schools played critical "bridge" roles in promoting and legitimating women's admission to colleges. I have found an advertisement for a "Female Collegiate Institute; at Belleville, New Jersey," Sentinel of Freedom (Newark), February 19, 1833. More research on collegiate institutes is necessary to determine when and how many of these institutions were established in the decades before women gained formal access to colleges.

${ }^{47}$ Aletta Van Dunk, Journal, May 12, 1828; May 28, 1828, and June 25, 1828, Special Collections, Alexander Library, Rutgers University, New Brunswick, NJ.

${ }^{48}$ Aletta Van Dunk, Journal, March 3 and 5, 1829. 
I have frequently wondered at the great distinction existing between the sexes. But why is this difference? Is not a Lady possessed of a mind equally capacious, and capable of expansion as that of a gentleman? Has not the Parent of the Universe, bestowed upon both equal talents to be cultivated? Then, why is it, that the female appears so inferior? Why that the other sex produce more literary characters? Why that we remain so dependent on, instead of endeavouring to surpass the Gentlemen, \& leaving the vale of Ignorance, . . . ascend the Hill of Science, with a firm, undaunted step, uncontented until we reach its cloud-capt summit? ... . [W]e, who are enjoying such superior advantages, should use every effort to advance in Science. ${ }^{49}$

As Aletta Van Dunk's comments suggest, educated women made connections between their acquisition of knowledge and the potential uses of their education. While prescriptive rhetoric stressed women's domestic and social roles, an increasing number of women began work as reformers, writers, and teachers, eager to enact identities for themselves as "makers of public opinion." ${ }^{50}$ Responding to these trends, educators at female seminaries and institutes increasingly sought to provide "useful" education best suited to women's increasing "sphere of action."

\section{"To Train Them for Usefulness": Expanding Educational Opportunities for Women}

Throughout the 1830 s and 1840 s, men and women continued to establish a variety of schools for women across New Jersey. Caroline Craig founded a seminary in Lawrenceville whose "plan of instruction is designed to embrace all those branches considered necessary to a thorough and finished education." The school offered a regulated course of study, including courses on evidences of Christianity, philosophy of natural history, astronomy, algebra, moral philosophy, rhetoric, and political economy. ${ }^{51}$ In Bordentown, the Spring Villa Seminary celebrated the intellectual acquirements of its students, dismissing those who might criticize the need to educate women with such thoroughness. In 1839, Rev. Baynard Hall, principal of a local school for boys, delivered an address at Spring Villa's examination ceremonies: "We are assembled to celebrate a triumph: a triumph of light over darkness, of knowledge over ignorance and prejudice.",52 Throughout his essay, Hall's tone was one of unabashed enthusiasm:

\footnotetext{
49 Aletta Van Dunk, Journal, November 18, 1829.

${ }^{50}$ Kelley, Learning to Stand and Speak, 9 and passim.

${ }^{51}$ Lawrenceville Female Seminary, Between Princeton and Trenton, New Jersey (Princeton: Robert E. Hornor, 1842), 3-4.

${ }^{52}$ Rev. Baynard R. Hall, An Address Delivered to the Young Ladies of the Spring-Villa Seminary, at Bordentown, N.J. (Burlington: Powell \& George Printers, 1839), 7. The Spring-Villa Seminary was established by A. N. Girault in the 1830s; it was originally called the "French and English Seminary for Young Ladies." See Prospectus of the French and English Seminary for Young Ladies, at Bordentown, New Jersey, under the Direction of A. N. Girault (Burlington: J. L. Powell, Printer, 1836).

Another well-respected female seminary established during this time was St. Mary's Hall in Burlington, founded by George Washington Doane. See An Appeal to Parents for Female Education on Christian Principles; With a Prospectus of St. Mary's Hall, Green Bank, Burlington, New Jersey (Burlington: J. L. Powell, 1837); “The Ladies' Mentor," Lady's Book (New York), July 1837, 46-48; and Helen Louise Shaw, The First Hundred Years of St. Mary's Hall on the Delaware: A Century of Private School
} 
I call on you, young ladies, to rejoice. Rejoice that practicability, propriety and necessity of female education, in the large and true sense of the term, was long since settled by your honored parents, as a truth no longer even to be questioned. I call on you, parents, to rejoice. Rejoice in the happy results of your principles. . . .. Teachers! rejoice. Rejoice in the rewards of your many labours . . . . And rejoice thou! O my country! for from this and sister schools shall come thy brightest gems, thy richest treasures, thy noblest ornaments, thy most impervious ramparts: -- be all thy daughters wise and good, and thy blood-bought liberties can never be bartered, can never be lost! ${ }^{53}$

Like many proponents of women's education, Hall insisted that women's pursuit of education benefited society and the nation as a whole. As Lady's Book stressed in 1835: "It is a good sign of the advance of society when attention is paid to the education of women. ${ }^{, 54}$ Harriet Cooke, who established the Bloomfield Female Seminary in 1837, agreed with such sentiments. At her seminary: "No reasonable expense has been spared to afford to its pupils every facility for the intellectual improvement that is enjoyed by the best Institutions in the country." The school was furnished "with Globes, Maps, Charts, $\& c .$, and the young ladies have access to a carefully selected library, containing a large number of valuable works of reference on literary, scientific and historical subjects." Students attended lectures in natural philosophy and chemistry, as well as "occasional classes in Mineralogy, Geology, and Conchology." Cooke's seminary maintained a reputation for scholarly excellence. The History of Education in New Jersey (published in 1899), asserted that Cooke's Seminary "was for northern New Jersey what the school of Emma Willard at Troy was for eastern New York."

While prescriptive literature continued to stress women's "sphere" and proper roles, educators maintained that women had the right to be as thoroughly educated as possible to prepare them for life's possibilities. As Cooke stressed in her seminary's catalogue: "In the education of their pupils, it is the chief aim of the Principals to develop and strengthen the powers of the mind; to draw out its own resources; to induce habits of independent thinking; in short, to train them for usefulness in whatever circumstances they may be placed." By stressing women's "usefulness" and "independent thinking," educators paved the way for women to pursue work in an ever-widening sphere of action

Education for Young Women Under the American Episcopal Church, 1837-1937 (Yardley, PA: Cook

Printers, 1936).

${ }^{53}$ Hall, An Address Delivered to the Young Ladies of the Spring-Villa Seminary, 8.

${ }^{54}$ Lady's Book (New York), January 1835, 22. Lady's Book was the precursor to the famous Godey's Lady's Book, edited by Sarah Hale.

${ }_{55}$ Circular of the Bloomfield Female Seminary (Newark: Printed at the Daily Advertiser Office, 1849), 3-4. Also see Catalogue of the Teachers and Pupils of the Bloomfield Female Seminary From its Establishment Until the Year 1843 (Bloomfield, NJ: 1843).

${ }^{56}$ David Murray, History of Education in New Jersey (Washington, D.C.: Government Printing Office, 1899), 147. Also see Joseph Fulford Folsom, ed., Bloomfield Old and New: An Historical Symposium by Several Authors (Bloomfield, NJ: Published by the Centennial Historical Committee, 1912), 83; and Charles E. Knox, "Bloomfield Township," in William H. Shaw, History of Essex and Hudson Counties, New Jersey (Philadelphia: Everts \& Peck, 1884) [online at: http://www.firstbaptistbloomfield.org/knoxhist.htm]. 
- as reformers, activists, educators, and missionaries. Cooke was proud of the fact that sixteen of her students went on to pursue foreign missionary work; while countless others enjoyed careers as teachers or missionaries in the American west. ${ }^{57}$

In the 1830s, Almira Hart Lincoln Phelps joined the ranks of New Jersey educators, and like Harriet Cooke, stressed the need to provide women with "useful" education. Phelps, the sister of Emma Willard, left her position at the Troy Female Seminary in upstate New York to begin an independent career. By this time, Phelps had established a national reputation as a leader in women's education, and was the author of several well-regarded textbooks and essays. Before arriving in New Jersey, Phelps settled in West Chester, Pennsylvania in 1838, at a seminary under the supervision of Dr. J. W. Cook. The 1838 Prospectus for the West Chester Young' Ladies Seminary noted that the school would provide education "as nearly as possible, to such as are most approved in the colleges of our country." "W8 While the school was not named a "college," or a "collegiate institute," the educators and trustees of the West Chester Seminary were outspoken and unapologetic about their collegiate course of study.

The school at West Chester suffered financial failure in 1839, and was forced to close. Soon after, Lincoln Phelps established the Female Institute at Rahway, New Jersey. The school opened on November $6^{\text {th }}, 1839$, with Lincoln Phelps at Principal, assisted by several teachers. Phelps brought to Rahway the same commitment to a collegiate course of study that she had begun in West Chester and Troy: "Mrs. Phelps will in this institution pursue the college plan of education." Students were divided into primary, junior, and senior departments. The curriculum for seniors included algebra, geometry, moral science, legal classics, logic, criticism, and intellectual philosophy. Music, drawing, painting, and several languages also were offered. In its first year of operation, over sixty young women enrolled at the Rahway Female Institute. They came from Plainfield, Woodbridge, Bricktown, Elizabeth, Morristown, Danville, and of course Rahway. Several students traveled from New York City and Pennsylvania to study with Phelps. 59

Phelps' philosophy of education reflected the era's ambivalence surrounding women's educational endeavors. In the face of criticism about the dangers of over-educating women, Phelps assured patrons that "we have no intention of tolerating any neglect of feminine duties or accomplishments." The chief aim of education, as Phelps insisted, was to "render woman a blessing and an ornament to society." The school promoted a

\footnotetext{
${ }^{57}$ Circular of the Bloomfield Female Seminary, 4; also see Harriet B. Cooke, Memories of My Life Work: The Autobiography of Mrs. Harriet B. Cooke (New York: Robert Charter \& Brothers, 1858).

${ }^{58}$ Prospectus of the West-Chester Young Ladies' Seminary, in West-Chester, Pennsylvania (Westchester: 1838), 2; also see Phelps' essay on education in this same prospectus. For various published notices of this school, see "Female Education," New York Spectator, October, 25, 1838; "Seminaries for Young Ladies," Lady's Book (New York), October 1838; and "The West Chester Young Ladies' Seminary, Chester County, Pennsylvania," Atkinson's Saturday Evening Post (Philadelphia), October 27, 1838. For biographical information on Phelps, see Emma Lydia Bolzau, Almira Hart Lincoln Phelps: Her Life and Work (Philadelphia, 1936).

${ }^{59}$ Lincoln Phelps, Catalogue of the Officers and Students of the Rahway Female Institute, for 1839-40, with Conditions, etc, and Annual Report (New York: F. J. Huntington and Co., 1840), 3-14.
} 
rigorous course of study, but discouraged what contemporaries would have considered excessive female ambition in language borrowed from critics of women's education: "We encourage female accomplishments, [but] would discountenance pedantry and the affectation of learning." Despite these disclaimers, Phelps remained unapologetic about the need to "elevate the standard of female education, and to advance its true interests." Most notably, Phelps offered "particular instruction" to young women intending to become teachers: "We believe that a double benefit is conferred on society, by introducing females to the only liberal profession which is open to them, and by furnishing schools and private families with well qualified teachers and governesses." 60 By insisting that women be trained properly as teachers, Phelps legitimated women's professional work and expanded the ways in which women could be useful in society.

Perhaps due to Phelps' noted reputation as an educator and author, newspapers throughout New Jersey, New York, and Philadelphia kept close track of the institute's progress. "A Friend to Education" noted that the Rahway Institute "is really deserving of more than passing commendation." The Philadelphia Inquirer commended both the curriculum and physical layout of Phelps' school: "It is seldom we meet with such perfect arrangement as the interior presents, for the College plan of study, which is adopted by Mrs. Phelps." According to this author, Phelps' school at Rahway was "one of the pleasantest establishments in our country." The New York Spectator reprinted a recommendation from a parent "desirous that other parents, who have daughters to educate, and who may not be aware of the merits of the Institute, may, when they become so, avail themselves of the great experience and peculiar qualifications of Mrs. Phelps." ${ }^{\prime 61}$

Newspapers also reported on the examination ceremonies held at the Rahway Institute. The New York Spectator expressed its approval of the "industry and talents of the pupils, the good judgment of the principal who planned the course, and the faithfulness and ability of the teachers who had the immediate superintendence of the classes." "It is to such seminaries as this," this author concluded, "that our country must look for the true elevation of the female character." According to an account published in the $U$. S. Gazette, the examinations at Rahway offered "an intellectual feast, not inferior to any previous one." Reviewing the quality of the examinations conducted by the students, the author noted: "We never listened to the like in a college with greater pleasure, and we presume that none ever deserved more credit." ${ }^{\text {"62 }}$ The Rahway Female Institute was on its way to achieving fame and prestige equal to that enjoyed by Troy Female Seminary; but in late 1841, Phelps left New Jersey to teach at the Patapso Female Institute in Maryland. ${ }^{63}$

\footnotetext{
${ }^{60}$ Phelps, Catalogue of the Officers and Students of the Rahway Female Institute, 12-14.

61 "Mrs. Lincoln Phelps' Institute, at Rahway, N.J.," North American and Daily Advertiser (Philadelphia), April 24, 1840; "Rahway Institute, New Jersey," Philadelphia Inquirer and Daily Courier, January 31, 1840; "Female Education," New York Spectator, August 26, 1840.

${ }^{62}$ New York Spectator, October 17, 1840; U. S. Gazette, April 28, 1841 (as quoted in Bolzau, Almira Hart Lincoln Phelps, 115-116).

${ }^{63}$ Phelps left Rahway in 1841 to work at the Patapsco Female Institute in Maryland. See Bolzau, Almira Hart Lincoln Phelps, 118. Young women in Rahway enjoyed continued access to education after Phelps' departure. Mention of the "Rahway Female Institute" in an 1846 publication noted that the school "has been for several years in successful operation." See John W. Barber and Henry Howe, Historical
} 
Throughout the 1830s and 1840s, New Jersey educators continued to promote a rigorous course of academic study for women. Hannah Hoyt urged students attending her female seminary in New Brunswick to "make a thorough, [rather] than an early finish of their school education, ... f for which several years of study are an indispensable requisite."64 The Freehold Young Ladies' Seminary emphasized that its "extensive" course of study "requires a longer period than is usually devoted to study by young Ladies; but it is believed not to be more extensive than the present state of society demands." 65 The Camden Young Ladies' Institute was "designed to occupy a place in the first rank of Seminaries for young ladies." As its Board of Examiners noted with approval: "The high standard of scholarship set up for graduates of the Institution has been abundantly sustained by the present class .... The Board look upon the school, in every department, as being marked by the highest state of moral and intellectual culture." ${ }^{66}$

Increasingly, female seminaries offered education that would "render their knowledge available and useful in every department of practical life." As Joel Hawes argued during an address delivered at the Camden Institute: "females need an education that will qualify them to be teachers - educators of children and youth."67 Stressing the need for high standards and for useful education, educators responded to the needs of young women who were pursuing teaching careers. Teaching was the most accessible occupation available to most nineteenth-century women, and became an increasingly accepted part of women's "sphere" of action and influence. Although female teachers remained underpaid and undervalued in most educational systems, by the mid-nineteenth century women played leading roles in the education of youth in common schools and other institutions. ${ }^{68}$

Collections of the State of New Jersey, Containing a General Collection of the Most Interesting Facts, Traditions, Biographical Sketches, Anecdotes, Etc. (New York: S. Tuttle, 1846), 189. An advertisement for the "Rahway Female Seminary" also appeared in the New York Evangelist, April 14, 1853.

${ }^{64}$ Catalogue of Miss Hoyt's Female Seminary: New Brunswick, New-Jersey, 1850-1 (New Brunswick: J. Terhune \& Son, 1851), 16; also see Catalogue of Miss Hoyt's Female Seminary, New-Brunswick, New Jersey, 1855 (New Brunswick: J. Terhune, 1855); Catalogue of the New-Brunswick Female Institute, Miss Hoyt, Principal, New-Brunswick, New-Jersey, 1861-2 (New Brunswick: Terhune \& Van Anglen's Press, 1862); and Demarest, "Some Early New Brunswick Schools for Girls."

${ }^{65}$ Catalogue of the Freehold Young Ladies' Seminary (March 1846), 2. The Freehold Young Ladies' Seminary remained in operation for several decades, at least through the 1880s. For more information, see Catalogue of the Instructors and Pupils of the Freehold Young Ladies'Seminary, Monmouth County, N.J., for the Year Ending Sept. 22, 1850 (NY: Spalding and Shepard, 1850). Several catalogues for the Freehold Young Ladies' Seminary remain extant, and can be found at Special Collections, Alexander Library, Rutgers University, New Brunswick, NJ.

${ }^{66}$ Joel Hawes, An Address Delivered at the Fourth Anniversary of the Camden Young Ladies' Institute: Camden, New Jersey, July 2, 1852 (Philadelphia: Crissy \& Markley, Printers, 1852), 22-27. To give additional weight to their endeavors, the Camden Institute also adopted the practice of issuing diplomas to those students who completed the full course of study.

${ }^{67}$ Hawes, An Address Delivered at the Fourth Anniversary of the Camden Young Ladies' Institute, 22-27.

${ }^{68}$ For the "feminization" of the teaching profession, see Jurgen Herbst, And Sadly Teach: Teacher Education and Professionalization in American Culture (Madison: University of Wisconsin Press, 1980), especially 24-30; Christopher J. Lucas, Teacher Education in America: Reform Agendas for the TwentyFirst Century (New York: St. Martin's Press, 1997), especially 12-15; and Jo Anne Preston, "Domestic Ideology, School Reformers, and Female Teachers: Schoolteaching Becomes Women's Work in Nineteenth-Century New England," The New England Quarterly (1993), 543-545. According to Lucas, 
By the 1840s, educators increasingly focused, as Phelps had in Rahway, on teacher training. Founded in 1843, the Mount Holly Female Seminary was "designed to unite a liberal and thorough education, literary, scientific, and practical, with the most careful attention to health, and faithful religious instruction." The school was divided into five departments, including a "Teachers Department" that offered specific instruction in the "Arts and Science of Instruction." "69 Between its founding in 1843 and 1848 (the date of the first published catalogue for the school), nearly one hundred young women enrolled at the Mount Holly Female Seminary. By mid-century, the establishment of normal schools, including the Paterson Normal School (now William Paterson University) and the New Jersey State Normal School at Trenton (now the College of New Jersey), created even more comprehensive curricula for the ever-growing number of women entering the teaching profession. ${ }^{70}$ Mount Holly Female Seminary was a forerunner to these normal schools, providing students the "opportunity to learn both the theory and practice of their profession, which, in this country, is becoming every day more important and arduous." Mount Holly was one of several seminaries in New Jersey that trained women to meet the practical challenges of their professional teaching careers.

As normal schools and seminaries promoted further advancements women's education, Reverend John Brakeley established the first college for women in New Jersey. Founded in 1851, the Bordentown Female College received a charter from the New Jersey state legislature in 1853, and remained in operation for nearly half a century. Its charter invested the Bordentown Female College "with all the powers and privileges of a corporation, for the permanent establishment of said college, to promote the moral and literary education of females." 72 In the second half of the nineteenth century, the history of women's education is dominated by women's entrance to normal schools and colleges, important developments that merit separate study and analysis. ${ }^{73}$ These developments

New Jersey was one of the first states, along with Vermont, Ohio, and Massachusetts, in which female teachers outnumbered their male counterparts in common and day schools (14).

${ }^{69}$ Catalogue and Prospectus of the Mount Holly Female Seminary (Philadelphia: Printed by Hogan \& Thompson, 1848), 5-7.

${ }^{70}$ For accounts of normal schools, see Charles A. Harper, A Century of Public Teacher Education (Washington, D.C.: National Education Association, 1939); Herbst, And Sadly Teach; Lucas, Teacher Education in America; Christine Ogren, The American State Normal School: "An Instrument of Great Good" (New York: Palgrave-Macmillan, 2005); and Donald R. Raichle, From a Normal Beginning: The Origins of Kean College of New Jersey (Rutherford: Fairleigh Dickinson University Press, 1980). While normal schools first were established in New England, New Jersey played an active role in promoting this type of educational training for teachers. The first convention of the American Normal School Association was held in Trenton, New Jersey, in 1859. See American Normal Schools: Their Theory, Their Workings, and Their Results, as Embodied in the Proceedings of the First Annual Convention of the American Normal School Association, Held at Trenton, New Jersey, August 19 and 20, 1859 (New York: Published by A. S. Barnes \& Burr, 1860).

${ }^{71}$ Catalogue and Prospectus of the Mount Holly Female Seminary, 5.

${ }^{72}$ Catalogue of the Officers and Students of the Bordentown Female College, of Bordentown, N.J. Chartered by the Legislature of the State of New Jersey, with Collegiate Powers and Privileges (Trenton: Benjamin F. Yard, 1853), 11; also see various articles on the college in Bordentown Register, May 25, 1923; June 17, 1898; February 1, 1895; June 12, 1891; and September 25, 1891.

${ }^{73}$ Recent studies have uncovered a complex, diverse history of women in higher education that extends beyond the "seven sister" colleges. Chartered in 1836 and opened in 1839, the Georgia Female College 
would not have been possible without the continually evolving efforts of educators in New Jersey during the first half of the nineteenth century to improve women's access to education.

\section{"Behold! Women are Educated": Conclusions}

By mid-century, many New Jersey supporters of women's education would have agreed with Baynard Hall's remarks during his 1839 speech at the Spring-Villa Seminary in Bordentown: "We are assembled, not by way of argument to set forth the advantages and practicability of female education, ... but simply to say, 'behold! Women are educated!"' Support by Baynard Hall, Henry Powers, John Brakeley and other prominent men helped assure credibility and continued support for female education. Yet ultimately, as Hall insisted, the lives and actions of female students "will silence the contemptuous, convince the skeptical, chase off the impertinent, [and] encourage the timid." "74 The experiences of nineteenth-century women who attended the seminaries and institutes established throughout New Jersey and the nation suggest that Hall's optimistic, celebratory comments rang true. As Godey's Lady Book proclaimed in 1840, the achievements of educated women "might put to the blush many [men] who graduate from our colleges." Institutional access to education opened up opportunities for women to gain paid employment as teachers and to pursue a variety of activist and reform work. Yet perhaps one of the most significant contributions provided by these schools was the widespread acceptance of women's education. ${ }^{76}$ By midcentury, the idea of sending women to college was no longer the "absurdity" Emma Willard and others had considered it to be in 1818. Although critics continued to warn about the effects of women's education, nineteenth-century women expanded the boundaries of their "native sphere" and successfully demonstrated their impressive talents as teachers, writers, and reformers.

Although largely overlooked in the historiography, the history of nineteenth-century New Jersey women's education reveals a variety of innovative schools that provided women with a full range of educational opportunities. The trends and innovations often considered unique to New England academies and seminaries can also be found in New Jersey's educational history, and the same may be true for other states across the nation. ${ }^{77}$

(known as Wesleyan College) in Macon, Georgia, is typically considered the first college for women founded in the United States. Mount Holyoke began operation in 1837 as a female seminary, but did not receive its college charter until 1888. In 1837, Oberlin College in Ohio became the first co-educational college to admit women; and in 1861 Vassar was the first of the "seven sister" colleges founded (the first class was admitted in 1865). In New Jersey, the Evelyn College at Princeton University admitted women during its decade-long existence from 1887-1897, and the New Jersey College for Women (now Douglass College) opened in 1918. For more information, see sources in note 9.

${ }^{74}$ Hall, An Address to the Young Ladies of the Spring-Villa Seminary, 3, 14.

${ }^{75}$ Hale, "Comparative Intellectual Character of the Sexes," 273.

${ }^{76}$ I am indebted to E. Jennifer Monaghan for this important insight.

77 The academies, seminaries, and institutes examined in this study may represent only a fraction of the total number of schools for women's education established throughout nineteenth-century New Jersey. As Mary Kelley suggests, historians typically have underestimated the number of women's schools, indicating the need for further research of state and local archives. See Kelley, Learning to Stand and Speak, 67-68, especially 68, n3. Kelley cites an unpublished study by Lynne Templeton Brickley indicating that "182 
The evidence uncovered to date clearly demonstrates the centrality of New Jersey to larger historical narratives and frameworks of the history of education. New Jersey schools conducted "bold experiments" in the education of women, offering collegiate courses of study decades before colleges for women opened, and providing teacher's training before normal schools were established. New Jersey schools continually met the changing standards and challenges of women's education, and were often at the forefront of changes in educational philosophy and curriculum. New Jersey educators supported women's education in strong, unapologetic terms, enabling women to take pride in their educational accomplishments and to pursue careers as teachers. New Jersey schools for women were indeed "equal in character with any other in the United States."

academies and at least 14 seminaries were established exclusively for women in the North and South" between 1790-1830. Between 1830 and 1860, "at least 158 more schools were opened." Since few New Jersey schools have been included in most published accounts of women's education to date, these numbers may be even higher. 
McMahon 